Jurnal Psikologi Malahayati, Volume 2, No.2, September 2020: 86-93

\title{
ASERTIVITAS DAN SUBJECTIVE WELL-BEING PADA MAHASISWA DI MASA PANDEMI COVID-19
}

\author{
Ika Apriati Widya Puteri
}

Program Studi Pendidikan Guru PAUD Universitas Widya Gama Mahakam Samarinda, email: ika_apriati@yahoo.com

\section{ABSTRACT: ASSERTIVENESS AND SUBJECTIVE WELL-BEING ON UNIVERSITY STUDENT IN THE COVID-19 PANDEMIC TIME}

This year, the global Covid-19 pandemic hit the world and affected various aspects of life, as well as in the world of education. The pandemic that is there is causing some psychological symptoms in the majority of people. The adaptation to this new situation affects students' subjective well-being. One of the factors related to subjective well being is assertiveness. The purpose of this study was to determine the relationship between assertiveness and subjective well-being among college students, especially in the global Covid- 19 pandemic situation. This research was conducted on 49 students of The Teacher Training and Education Faculty, Widya Gama Mahakam University Samarinda. This study uses an instrument of assertiveness scale, the scale of Satisfaction with Life Scale, and the Scale of Positive and Negative Experience. The analysis was performed using Pearson's product moment correlation technique. The results showed that there was no relationship between assertiveness and subjective well-being in the students of the Teaching and Education Faculty, Widya Gama Mahakam University Samarinda.

\section{Keywords: Assertiveness, Subjective Well-Being, University Student}

Tahun ini, pandemi global Covid-19 melanda dunia dan mempengaruhi berbagai aspek kehidupan, begitu pula dalam dunia pendidikan. Pandemi yang ada menimbulkan beberapa gejala psikologis pada sebagian besar orang. Adaptasi terhadap situasi yang baru ini mempengaruhi kesejahteraan subjektif (subjective well-being) mahasiswa. Salah satu faktor yang berhubungan dengan subjective well-being adalah asertivitas. Tujuan dari penelitian ini adalah untuk mengetahui hubungan antara asertivitas dan subjective well-being pada mahasiswa, khususnya pada situasi pandemi global Covid-19. Penelitian ini dilakukan terhadap 49 mahasiswa Fakultas Keguruan dan IImu Pendidikan Universitas Widya Gama Mahakam Samarinda. Penelitian ini menggunakan instrumen skala asertivitas, skala Satisfaction with Life Scale, dan Scale of Positive and Negative Experience. Analisis dilakukan dengan teknik korelasi product moment dari Pearson. Hasil penelitian menujukkan bahwa tidak ada hubungan antara Asertivitas dan Subjective Well-Being pada Mahasiswa Fakultas Keguruan dan IImu Pendidikan Universitas Widya Gama Mahakam Samarinda.

\section{Kata Kunci: Asertivitas, Subjective Well-Being, Mahasiswa}

\section{PENDAHULUAN}

Tahun 2020 tidak berjalan seperti yang kebanyakan dipikirkan oleh setiap individu. Pada tahun ini, pandemi global Covid-19 melanda dunia dan mempengaruhi berbagai aspek kehidupan, begitu pula dalam dunia pendidikan. Pandemi yang ada menimbulkan beberapa gejala psikologis pada sebagian besar orang. Dampak yang terasa pada mahasiswa dari pandemi global ini adalah bergesernya platform pembelajaran dari pertemuan tatap muka menjadi pertemuan yang dilakukan secara daring. Beberapa mahasiswa mengalami 
Jurnal Psikologi Malahayati, Volume 2, No.2, September 2020: 86-93

\section{ASERTIVITAS DAN SUBJECTIVE WELL-BEING PADA MAHASISWA DI MASA PANDEMI COVID-19}

kesulitan dalam transisi ini dikarenakan beberapa hal, seperti lokasi tempat tinggal yang sulit mendapatkan jaringan internet, pendapatan orangtua yang terpengaruh pandemi sehingga mereka tidak memiliki dana untuk membeli kuota internet, serta rasa cemas dan gelisah karena pandemi membatasi mereka dalam melakukan aktivitas dan juga tugas-tugas perkuliahan. Adaptasi terhadap situasi yang baru ini mempengaruhi kesejahteraan subjektif (subjective well-being) mahasiswa itu sendiri. Subjective well-being sering disamakan dengan istilah kebahagiaan pada beberapa literatur psikologi walaupun sebenarnya tidak benar-benar sama. Kebahagiaan adalah kondisi emosi positif yang didefinisikan oleh individu secara subjektif. Kebahagiaan merupakan salah satu bagian dari subjective well-being (Lopez, Pedrotti, \& Snyder, 2018).

Subjective well-being merupakan kombinasi dari adanya afek positif dan kepuasan hidup secara umum serta tidak adanya afek negatif (Diener, 1984; Diener \& Scollon, 2003). Menurut Toussaint dan Friedman (2009), definisi tersebut menyebutkan ada 3 komponen subjective well-being yaitu: (1) Kepuasan hidup tinggi yang termasuk komponen kognitif. Kepuasan hidup adalah penilaian individu terhadap kualitas kehidupannya secara umum atau terhadap beberapa aspek kehidupan, seperti pekerjaan, pernikahan, dan sekolah (Basson, 2008). Individu menilai hidupnya dengan standar apakah keinginannya terpenuhi dalam kehidupannya, apakah memuaskan, ataukah mempunyai arti baik

Ika Apriati Widya Puteri, Program Studi Pendidikan Guru PAUD Universitas Widya Gama Mahakam Samarinda. Email: ika apriati@yahoo.com bagi diri sendiri maupun orang lain (Diener \& Oishi, 2004). (2) Afek positif yang tinggi ditandai dengan seberapa sering individu merasakan afek positif, seperti keceriaan dan kebahagiaan (Diener \& Oishi, 2004). Hubungan sosial dengan keluarga dan orang lain berhubungan sangat erat dengan afek positif dan dapat meningkatkan subjective well-being individu (Diener \& Oishi, 2005). Faktor-faktor lain yang berhubungan dengan afek positif yaitu jumlah teman dekat dan kerabat, keterlibatan dalam organisasi sosial, kegiatan sosial secara umum, sifat yang terbuka, aktivitas fisik dan olahraga, dan religiusitas. Ketika individu merasakan afek positif maka individu tersebut cenderung akan menolong orang lain, lebih fleksibel dalam berpikir, dan mempunyai solusi untuk memecahkan permasalahannya (Lopez, Pedrotti, \& Snyder, 2018). (3) Afek negatif yang rendah ditandai dengan individu yang jarang merasakan afek negatif seperti kesedihan, perasaan tidak menyenangkan, dan marah (Diener \& Oishi, 2004).

Seseorang dikatakan mempunyai subjective well-being yang tinggi jika orang tersebut merasakan kepuasan dalam hidup, sering merasakan emosi positif dan jarang merasakan emosi negatif. Subjective well-being merupakan total skor darikepuasan hidup ditambah dengan afek positif dan dikurangi dengan afek negatif. Di bawah ini adalah rumusannya : 
Jurnal Psikologi Malahayati, Volume 2, No.2, September 2020: 86-93

\section{ASERTIVITAS DAN SUBJECTIVE WELL-BEING PADA MAHASISWA DI MASA PANDEMI COVID-19}

\section{Gambar 1}

\section{Formula Penghitungan Subjective Well Being}

Subjective well-being = kepuasan hidup + (afek positf - atek negatif')

Berdasarkan hasil wawancara singkat pada beberapa mahasiswa, mereka mengatakan bahwa situasi pandemi ini cukup memiliki dampak pada diri mereka sendiri. Terutama dalam hal afek positif karena mahasiswa akhirnya memiliki keterbatasan dalam melakukan aktivitas sosial dengan orang lain. Belum lagi dengan banyaknya berita mengenai pandemi, baik yang dapat dipercaya maupun yang bersifat hoax turut mempengaruhi perilaku mereka. Pada bulan-bulan awal pandemi melanda di Samarinda, yaitu sekitar Maret-April 2020, para mahasiswa sempat merasa cemas sehingga mereka benar-benar tidak melakukan aktivitas di luar tempat tinggalnya. Beberapa mahasiswa memutuskan untuk pulang kampung agar lebih dekat dengan keluarga masing-masing, walaupun pada akhirnya berdampak pada sulitnya akses internet di kampung halaman, yang menyulitkan mereka mengikuti perkuliahan secara daring. Hal ini tentu saja menjadi stresor tersendiri bagi mahasiswa dan mempengaruhi afek mereka. Hidalgo, Bravo, Martinez, Pretel, Postigo, dan Rabadan (2010) menyatakan bahwa well-being memiliki hubungan positif dengan kepuasan hidup, dan self-esteem, serta berhubungan negatif terhadap kecemasan, stres dan depresi, yang artinya ketika individu mengalami kecemasan atau stres maka akan mempengaruhi tingkat well-being yang dimiliki individu. Penelitian Howell, Kern dan Lyubomirsky, 2007 (Hidalgo, Bravo, Martinez, Pretel, Postigo, \& Rabadan 2010) menyatakan bahwa psychological well-being memiliki dampak langsung dalam memperkuat sistem kekebalan tubuh dan membantu menetralisir dampak stres.

Alberti dan Emmons (2002) menyatakan dengan adanya pencapaian pengungkapan diri maka akan memberikan dampak langsung bagi individu tersebut yakni telah meningkatkan selfesteemnya, mengurangi kecemasannya, mengatasi depresinya, mendapatkan penghargaan yang lebih besar dari orang lain, mencapai lebih banyak lagi tujuan hidupnya, meningkatkan tahap pemahaman diri, dan memperbaiki komunikasi yang lebih efektif dengan orang lain dan meningkatkan hubungan kita dengan orang lain. Pengungkapan diri ini dinamakan sebagai asertivitas.

Rim dan Masters mengatakan bahwa asertivitas atau perilaku asertif adalah perilaku dalam hubungan interpersonal yang bersifat jujur dan mengekspresikan pikiran-pikiran dan perasaan dengan memperhitungkan kondisi sosial yang ada (Rakos, 1991). Orang yang asertif adalah orang yang penuh semangat menyadari siapa dirinya, apa yang diinginkan dan benar-benar yakin pada dirinya sendiri. Menurut Lloyd (1991) asertif dikatakan sebagai gaya wajar, langsung, jujur dalam mengekspresikan perasaan, adanya sikap menghormati dalam interaksi, dan dapat diekspresikan, baik secara verbal maupun denganmenampilkan bahasa tubuh yang serasi.

Ika Apriati Widya Puteri, Program Studi Pendidikan Guru PAUD Universitas Widya Gama Mahakam Samarinda. Email: ika apriati@yahoo.com 
Jurnal Psikologi Malahayati, Volume 2, No.2, September 2020: 86-93

\section{ASERTIVITAS DAN SUBJECTIVE WELL-BEING PADA MAHASISWA DI MASA PANDEMI COVID-19}

Individu yang asertif memandang keinginan, kebutuhan, dan hak-hak pribadinya sama dengan keinginan, kebutuhan, dan hak-hak dari orang lain.

Asertivitas yang dikemukakan Stein dan Book (2011) yaitu ketegasan, berani menyatakan pendapat. Asertivitas ini meliputi aspek-aspek sebagai berikut: (1) Kemampuan mengungkapkan perasaan secara langsung dan jujur. (2) Kemampuan mengungkapkan keyakinan dan pemikiran secara terbuka, baik untuk suatu hal yang disetujui maupun tidak disetujui. (3) Kemampuan untuk mempertahankan hak-hak pribadi, yaitu tidak membiarkan orang lain mengganggu dan memanfaatkannya.

Tujuan dari penelitian ini adalah untuk mengetahui hubungan antara asertivitas dan subjective well-being pada mahasiswa Fakultas Keguruan dan IImu Pendidikan Universitas Widya Gama Mahakam Samarinda, khususnya pada situasi pandemi global Covid-19.

\section{METODE}

Subjek penelitian ini adalah 49 mahasiswa Fakultas Keguruan dan IImu Pendidikan Universitas Widya Gama Mahakam Samarinda dengan rentang usia 18-31 tahun. Variabel bebas penelitian adalah asertivitas yaitu kemampuan sesorang untuk menyampaikan pikiran dan perasaannya dengan cara yang positif dan tidak menyinggung orang lain. Variabel tergantung dari penelitian ini adalah subjective well-being, yaitu evaluasi subjektif yang dilakukan individu terhadap kehidupannya.
Subjective well-being merupakan kombinasi dari adanya afek positif dan kepuasan hidup yang tinggi serta tidak adanya afek negatif.

Pengukuran dalam penelitian ini menggunakan 3 buah instrumen, yaitu skala asertivitas, satisfaction with life scale, dan scale of positive and negative experience (SPANE). Skala Asertivitas dari Setyaningrum (2013) terdiri dari 36 butir untuk mengukur tingkat asertivitas mahasiswa. Skala ini terdiri dari 4 pilihan jawaban yaitu sangat sesuai (SS), sesuai (S), tidak sesuai (TS), dan sangat tidak sesuai (STS). Selanjutnya, skala Satisfaction with Life Scale dari Diener (1985) terdiri dari 5 butir yang digunakan untuk mengetahui tingkat kepuasan hidup seseorang. Skala ini berbentuk interval dengan rentang penilaian mulai 1 (sangat tidak setuju) hingga 7 (sangat setuju). Skor yang tinggi menunjukkan seseorang memiliki tingkat kepuasan hidup yang tinggi pula. Scale of Positive and Negative Experience (SPANE) dari Diener (2009) terbagi menjadi dua bagian, yaitu SPANE-P untuk afek positif yang terdiri dari 6 butir dan SPANE-N untuk afek negatif yang terdiri dari 6 butir. Skala ini berbentuk interval dengan rentang penilaian 1 (sangat jarang/tidak pernah) hingga 5 (sangat sering/selalu). Skor yang tinggi pada butir perasaan positif menunjukkan afek positif yang tinggi, sedangkan skala yang tinggi pada butir perasaan negatif menunjukkan afek negatif yang tinggi pada seseorang.

Sebelum suatu alat ukur digunakan untuk penelitian harus diuji terlebih dahuluvaliditas dan

Ika Apriati Widya Puteri, Program Studi Pendidikan Guru PAUD Universitas Widya Gama Mahakam Samarinda. Email: ika apriati@yahoo.com 
Jurnal Psikologi Malahayati, Volume 2, No.2, September 2020: 86-93

\section{ASERTIVITAS DAN SUBJECTIVE WELL-BEING PADA MAHASISWA DI MASA PANDEMI COVID-19}

reliabilitasnya. Penelitian ini menggunakan kategori validitas isi, yaitu sejauh mana butir-butir tesmewakili komponen-komponen dalam keseluruhan kawasan isi objek yang hendak diukur (aspek representasi) dan sejauh mana butir-butir tes mencerminkan ciriperilaku yang hendak diukur (aspek relevansi) (Azwar, 2001). Sedangkan untuk reliabilitas ditemukan bahwa Skala Asertivitas $(a=$ .786), Satisfaction with Life Scale $(\alpha=.722)$, dan Scale of Positive and Negative Experience $(\alpha=.811$ untuk SPANE-P dan $a=.829$ untuk SPANE-N sehingga dapar disimpulkan ketiga instrument reliabel.

Teknik analisis data yang digunakan untuk mengetahui hubungan antara dua variabel adalah teknik korelasi product moment dari Pearson karena teknik korelasi dari Pearson dapat mengungkap hubungan antar variabel seperti yang terdapat pada hipotesis. Analisis data menggunakan SPSS for Windows versi 16 .

\section{HASIL}

Sebelum dilakukan analisis data penelitian, maka terlebih dahulu dilakukan uji normalitas sebaran dan uji liniearitas data penelitian. Uji normalitas dilakukan untuk melihat apakah bentuk sebaran data empirik mengikuti bentuk sebaran data normal teoritik. Uji normalitas ini menggunakan teknik statistik Kolmogorov Smirnov dengan program SPSS for windows versi 11. Berdasarkan hasil uji normalitas, sebaran data adalah normal $(\mathrm{KS}-\mathrm{Z}=0.518, \mathrm{p}>.05)$. Uji linearitas bertujuan untuk melihat apakah sebaran titik-titik yang merupakan nilai variabel-variabel penelitian dapat ditarik garis lurus yang menunjukkan hubungan linear antara variabel-variabel tersebut. Hasil uji linearitas menunjukkan nilai $p=0,625$ yang berarti penyimpangan terhadap linieritas tidak signifikan sehingga data dapat dikatakan linier.

Berdasarkan data penelitian ditemukan bahwa $65.31 \%$ subjek memiliki tingkat asertivitas pada kategori sedang, 20.41\% kategori rendah, dan $14.28 \%$ kategori tinggi. Hal ini menunjukkan secara keseluruhan, mahasiswa Fakultas Keguruan dan IImu Pendidikan Universitas Widya Gama Mahakam Samarinda memiliki tingkat asertivitas pada taraf sedang. Selain itu, penelitian juga menemukan bahwa $69.395 \%$ subjek memiliki tingkat subjective well-being sedang, $16.33 \%$ tinggi, dan $14.28 \%$ rendah. Hal ini menunjukkan secara keseluruhan, mahasiswa Fakultas Keguruan dan IImu Pendidikan Universitas Widya Gama Mahakam Samarinda memiliki tingkat subjective well-being pada taraf sedang.

Analisis data penelitian menggunakan teknik korelasi product moment dari Pearson dengan menggunakan program SPSS for windows versi 16 untuk mengukur signifikansi hubungan antara dua variabel. Hasil analisis menunjukkan bahwa tidak ada hubungan yang signifikan antara asertivitas dan subjective well-being mahasiswa Fakultas Keguruan dan IImu Pendidikan Universitas Widya Gama Mahakam Samarinda. $(r(49)=.096, p>.05)$.

Ika Apriati Widya Puteri, Program Studi Pendidikan Guru PAUD Universitas Widya Gama Mahakam Samarinda. Email: ika apriati@yahoo.com 
Jurnal Psikologi Malahayati, Volume 2, No.2, September 2020: 86-93

\section{ASERTIVITAS DAN SUBJECTIVE WELL-BEING PADA MAHASISWA DI MASA PANDEMI COVID-19}

\section{Tabel 1}

Uji Korelasi Asertivitas dengan Subjective Well Being

\begin{tabular}{ll}
\hline & Subjective Well Being \\
\hline Asertivitas & $r=.096$ \\
\hline
\end{tabular}

DISKUSI

Secara kuantitatif, tidak terdapat hubungan yang signifikan antara asertivitas dan subjective well-being mahasiswa Fakultas Keguruan dan IImu Pendidikan Universitas Widya Gama Mahakam Samarinda. Walaupun demikian, temuan penelitian ini menunjukkan bahwa subjek memiliki tingkat asertivitas yang cukup tinggi $(79,59 \%)$ dan memiliki tingkat subjective well-being yang cukup tinggi pula $(85,72 \%)$. Faktor yang mempengaruhi subjective well-being sendiri cukup luas. Hal ini meliputi emosi pengalaman menyenangkan, rendahnya tingkat mood negatif, dan kepuasan hidup yang tinggi (Diener, Lucas, \& Oishi dalam Arbiyah, Imelda, \& Oriza, 2008). Istilah subjective well-being didefinisikan sebagai evaluasi kognitif dan afektif seseorang tentang hidupnya. Evaluasi ini meliputi penilaian emosional terhadap berbagai kejadian yang dialami yang sejalan dengan penilaian kognitif terhadap kepuasan dan pemenuhan hidup (Diener, Lucas, \& Oishi dalam Arbiyah dkk, 2008).

Subjective well-being tersusun dari beberapa komponen utama, termasuk kepuasan hidup secara umum, kepuasan terhadap ranah spesifik kehidupan, adanya afek yang positif (mood dan emosi yang menyenangkan), dan ketiadaan afek negatif (mood dan emosi yang tidak menyenangkan) (Eddington \& Shuman dalam
Arbiyah dkk, 2008). Asertivitas adalah perilaku dalam hubungan interpersonal yang bersifat jujur dan mengekspresikan pikiran-pikiran dan perasaan dengan memperhitungkan kondisi sosial yang ada (Rim dan Masters dalam Rakos, 1991). Perilaku asertif membuat seseorang mampu mengekspresikan diri sekaligus menghormati hakhak orang lain. Hal ini meningkatkan kualitas hubungan dengan orang lain, meningkatkan selfesteem, mengurangi kecemasan dan mengurangi tingkat depresi (Marwan, Tt). Pernyataan ini menunjukkan asertivitas atau perilaku asertif memiliki hubungan pada afek yang dialami oleh seseorang, sehingga belum memiliki representasi secara langsung dengan subjective well-being yang merupakan gabungan dari kepuasan hidup dan tinggi afeknya positif yang dirasakan oleh inividu. Nilai asertivitas yang cukup tinggi pada subjek penelitian menunjukkan bahwa subjek sebagian besar mampu berperilaku asertif, seperti memiliki ketegasan dan berani menyatakan pendapat (Stein \& Book, 2011). Hal ini pun terlihat dalam interaksi yang dilakukan oleh mahasiswa dan dosen selama proses pembelajaran daring, baik melalui platform google classroom, aplikasi whatsapp messenger, maupun zoom cloud meeting. Selama proses pembelajaran daring di masa pandemi Covid-19 ini, mahasiswa terlihat lebih aktif

Ika Apriati Widya Puteri, Program Studi Pendidikan Guru PAUD Universitas Widya Gama Mahakam Samarinda. Email: ika apriati@yahoo.com 
Jurnal Psikologi Malahayati, Volume 2, No.2, September 2020: 86-93

\section{ASERTIVITAS DAN SUBJECTIVE WELL-BEING PADA MAHASISWA DI MASA PANDEMI COVID-19}

dan tidak ragu untuk menyatakan pendapatnya saat perkuliahan. Hal ini berbeda dengan saat perkuliahan dilakukan secara tatap muka. Hal ini cukup sejalan dengan tingkat subjective well-being pada subjek yang juga cukup tinggi. Subjek memiliki skor yang cukup tinggi pada skala kepuasan hidup. Namun, tidak demikian pada skala afek. Terdapat 14 subjek yang memiliki skor afek di bawah 0 , dan 24 subjek yang memiliki skor afek di bawah 10. Hal ini menunjukkan, bahwa secara umum, para subjek cenderung lebih banyak merasakan afek negatif dalam kehidupannya. Rendahnya skor afek ini menyebabkan tingkat subjective well-being dari mahasiswa Fakultas Keguruan dan IImu Pendidikan Universitas Widya Gama Mahakam Samarinda sebagian besar hanya berada pada kategori sedang. Asertivitas yang cukup tinggi sendiri, tidak selalu membuat subjek merasakan afek yang positif dalam kehidupannya sehari-hari, sehingga berimplikasi pada tingkat subjective well-being seseorang. Penelitian Dewi dan Nasywa (2019) menemukan bahwa terdapat beberapa faktor yang mempengaruhi subjective well-being seseorang, yaitu dukungan sosial, kebersyukuran, fogiveness, personality, self-esteem, dan spritualitas. Asertivitas sendiri merupakan bagian dari self-esteem, sehingga tidak memiliki hubungan langsung dengan subjective well-being. Hal inilah yang menyebabkan walaupun tingkat asertivitas mahasiswa cukup tinggi, namun tidak memiliki hubungan yang signifikan dengan subjective well-being .

\section{SIMPULAN DAN SARAN}

Tidak ada hubungan yang signifikan antara asertivitas dan subjective well-being pada mahasiswa Fakultas Keguruan dan IImu Pendidikan Universitas Widya Gama Mahakam Samarinda. Namun demikian, tingkat asertivitas dan tingkat subjective well-being subjek berada pada tingkat sedang, yaitu asertivitas sebesar $65.31 \%$ dan subjective well-being sebesar $69.395 \%$. Hal ini disebabkan, subjek cenderung mengalami afek negatif yang cukup besar pada komponen subjective well-being. Selain itu, asertivitas sendiri tidak memiliki hubungan langsung dengan subjective well-being yang lebih banyak dipengaruhi oleh dukungan sosial, kebersyukuran, fogiveness, personality, self-esteem, dan spritualitas

Untuk penelitian selanjutnya, peneliti dapat mengontrol faktor lain seperti jenis kelamin, karena mahasiswa di Fakultas Keguruan dan IImu Pendidikan lebih banyak didominasi oleh mahasiswi perempuan, sehingga mungkin berpengaruh pada afek yang dirasakan.

\section{DAFTAR PUSTAKA}

Alberti, R., \& Emmons, M. (2002). Your Perfect Right (Hidup Lebih Bahagia dengan Mengungkapkan Hak). Jakarta: Elex Media Komputindo.

Arbiyah, N., Imelda, F. N., \& Oriza, I. D. (2008). Hubungan bersyukur dan subjective well being pada penduduk miskin. Universitas Indonesia, 14(01).

Azwar, S. (2001). Dasar-Dasar Psikometri Edisi 2. Yogyakarta: Pustaka Pelajar.

Ika Apriati Widya Puteri, Program Studi Pendidikan Guru PAUD Universitas Widya Gama Mahakam Samarinda. Email: ika apriati@yahoo.com 
Jurnal Psikologi Malahayati, Volume 2, No.2, September 2020: 86-93

\section{ASERTIVITAS DAN SUBJECTIVE WELL-BEING PADA MAHASISWA DI MASA PANDEMI} COVID-19

Basson, N. (2008). The influence of psychosocial factors on the subjective well-being of adolescents (Doctoral dissertation, University of the Free State).

Dewi, L., \& Nasywa, N. (2019). Faktor-faktor yang Mempengaruhi Subjective Well-Being. Jurnal Psikologi Terapan dan Pendidikan Vol. 1 No. 1, Mei 2019, pp 54-62

Diener, E. (2009). Subjective well-being. In The science of well-being (pp. 11-58). Springer, Dordrecht.

Diener, E., \& Scollon, C. (2003, October). Subjective well-being is desirable, but not the summum bonum. article présenté à la conférence University of Minnesota Interdisciplinary Workshop on Well-Being, Minneapolis.

Diener, E. (2003). Are Scandinavians Happier than Asians? Issues in comparing nations on subjective well-being. Palitics and economics of Asia.

Diener, E., \& Oishi, S. (2005). The nonobvious social psychology of happiness. Psychological Inquiry, 16(4), 162-167.

Hidalgo, J. L. T., Bravo, B. N., Martínez, I. P., Pretel, F. A., Postigo, J. M., \& Rabadán, F. E. (2010). Psychological well-being, assessment tools and related factors. IE Wells, Psychological well being, 77-113.

Lloyd, S. R., \& Budiyanto, F. X. (1991). Mengembangkan perilaku asertif yang positif. Binarupa Aksara, Jakarta.

Marwan, I.A. (Tt). Peranan Perilaku Asertif dan Diosentrisme terhadap Kesejahteraan Subyektif pada Orang Jawa dan Orang Batak. Skripsi Membership pada Perpustakaan Universitas Indonesia (tidak diterbitkan).
Rakos, F.R. (1991). Assertion Behaviour. New York: Routledge Champman dan Hall,Inc.

Setyaningrum, R. (2013). Hubungan antara Konsep Diri dengan Asertivitas pada Kelas XI di SMA Negeri 1 Kota Mungkid Magelang. Skripsi (tidak diterbitkan). Fakultas IImu Pendidikan Universitas Negeri Yogyakarta

Lopez, S. J., Pedrotti, J. T., \& Snyder, C. R. (2018). Positive psychology: The scientific and practical explorations of human strengths. Sage Publications.

Stein, S. J., \& Book, H. E. (2011). The EQ edge: Emotional intelligence and your success. John Wiley \& Sons.

Toussaint, L., \& Friedman, P. (2009). Forgiveness, gratitude, and well-being: The mediating role of affect and beliefs. Journal of Happiness Studies, 10(6), 635.

Ika Apriati Widya Puteri, Program Studi Pendidikan Guru PAUD Universitas Widya Gama Mahakam Samarinda. Email: ika apriati@yahoo.com 